\title{
Interrelation between Oral Health Status and Autism: A Case Report
}

\author{
Sirma Angelova* \\ Department of Pediatric Dentistry, Medical University-Varna, Bulgaria
}

Submission: February 05, 2019; Published: March 01, 2019

*Corresponding author: Sirma Angelova, Medical University-Varna, Faculty of Dental Medicine, Department of Pediatric Dentistry, Varna, Bulgaria

\begin{abstract}
Children suffering from autism are most often unable to collaborate to doctor during dental procedures, which results in restricted access to dental services. The application of antiepileptic drugs, associated to the main common health disorder, can provoke initiation or progression of gingival hyperplasia. The aim of our study is to investigate the interrelation between the oral health status and condition of autism in child's age in the context of a case report. The individual dental status registration ascertains a clinical finding of totally caries-resistant mixed dentition. It concerns a patient with very good personal oral hygiene. There are no signs of clinical manifestation of gingival inflammation. We accentuate on the fact that maintenance of proper common health status and oral health, respectively high quality of life, can be provided and ensured for children suffering from autistic spectrum disorder only when parents, dental medicine doctors and physicians of different professional scopes combine their efforts and collaborate with each other.
\end{abstract}

Keywords: Oral health; Autism; Antiepileptic medicines; Child's age

\section{Introduction}

The autistic spectrum disorder (ASD) is related to disabilities of proper communication and lack of adequate social relationships [1]. Autism is characterized as a disease of the Autism Spectrum Disorder (ASD) [2-4].

The distribution of autism is not associated to the racial traits, social-economic conditions of living and educational level of affected individuals and their families. Classic autism is related to diminished rate of language development, strict adherence to routines, hyperactivity, disability of concentration and attention [2-4].

Oral manifestations of autism are associated to clinical findings of erosion because of regurgitation, improper oral hygiene status, bruxism, tongue thrusting [2-4]. Children suffering from autism are most often unable to collaborate to doctor during dental procedures, which results in restricted access to dental services $[5,6]$. There is a considerable risk of seizure attacks, especially provoked during dental treatment of such patients. This is one of the most essential reasons for such children to accept antiepileptic drugs (AEDs), surgical treatment or vagus nerve stimulation [7]. The application of antiepileptic drugs can provoke initiation or progression of gingival hyperplasia $(\mathrm{GH})[7,8]$. The state of gingival hyperplasia is related to disturbed balance and control of the growth of gingival epithelium and sub-epithelial connective tissue. This condition of overgrowth of gingiva stimulates the process of pathological accumulation of dental plaque, accompanied by bleeding in the region of gingival sulcus and interdental papillae. The inflammatory process hinders the procedures of maintenance of full of value oral hygiene level, leading to deterioration of oral health status [7,9-26]. These adverse effects of antiepileptic drugs' usage can be overcome by performance of complex professional and individual oral hygiene cares. For the purposes of compensation of the negative consequences of antiepileptic drugs' application, patients of child's age and parents must participate in programs of prevention and educational sessions for promotion of oral health [7].

\section{Clinical Case}

The current study has been performed to assess the oral health status of a child suffering from autism. We investigate the personal oral hygiene level in the role of protective factor against tooth decay and gingival inflammation. Based on scientific literature concerning various methods of evaluation of oral health in patients going through antiepileptic therapy, especially in condition of autism [27-29], we have accentuated on registration of these indicators:

a. Plaque index related to illustration of the presence of dental plaque and its quantity on teeth surfaces, corresponding to the personal oral hygiene level $\rightarrow$ namely PLI Silness-Lòe; 
b. Index of gingival inflammation regarding alteration of gingival tissue color, presence or absence of edema and/or bleeding $\rightarrow$ namely GI Lòe-Silness;

c. Depth of probing, with measurement of the values of gingival pockets at medial, central and distal areas of vestibular and oral surfaces around each tooth;

d. Assessment of the frequency of oral hygiene procedures, especially tooth brushing with tooth pastes appropriate to child's age characteristics.

On Figure 1 we illustrate the interrelations between autism spectrum disorder, antiepileptic drugs and oral health. We represent a clinical case of a child at the age of 5 years and 1 month suffering from autism, with anamnestic data for epileptic seizures. Epileptic seizures' attacks have been controlled by acceptance of Valproic acid-containing medicine of Convulex and Neurotop, with the basic ingredient of Carbamazepine.

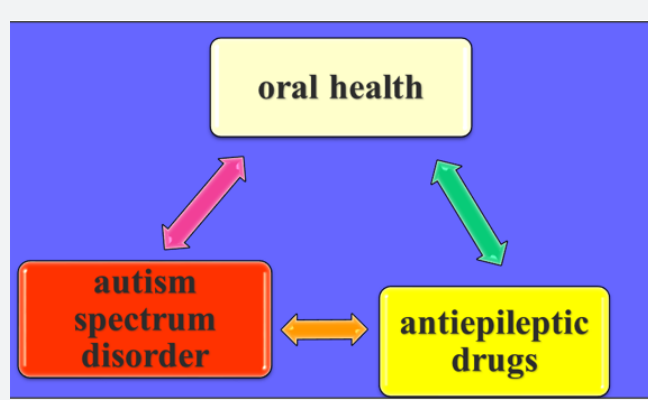

Figure 1: Interrelations between antiepileptic drugs and oral health in condition of autism.

The individual dental status registration ascertains a clinical finding of totally caries-resistant mixed dentition, with all the 20 primary upper and lower teeth unaffected by carious process. There are no lesions of type D1a, D1b, D2, D3a, D3b, as well as D4. We record presence of tooth 41 in pre-functional eruptive phase, with lingual location to tooth 81 (Figure 2).

\begin{tabular}{|c|c|c|c|c|c|c|c|c|c|c|c|c|c|c|c|}
\hline \multicolumn{16}{|c|}{ Dental Status } \\
\hline & & & 55 & & (53) & (52) & (5) & (61) & (62) & 63 & 64 & 65 & & & \\
\hline 18 & 17 & 16 & 15 & 14 & 13 & 12 & 11 & 21 & 22 & 23 & 24 & 25 & 26 & $27 \mid$ & 28 \\
\hline $\mathbf{x}$ & $\mathbf{x}$ & $\mathbf{x}$ & H & $\mathbf{H}$ & $\mathbf{H}$ & $\mathbf{H}$ & H & $\mathbf{H}$ & $\mathbf{H}$ & H & H & $\mathbf{H}$ & $\mathbf{x}$ & $\mathbf{x}$ & $\mathbf{x}$ \\
\hline $\mathbf{x}$ & $\mathbf{x}$ & $\mathbf{x}$ & $\mathbf{H}$ & $\mathbf{H}$ & H & $\mathbf{H}$ & $\mathbf{H} / \uparrow$ & $\mathbf{H}$ & $\mathbf{H}$ & $\mathbf{H}$ & $\mathbf{H}$ & $\mathbf{H}$ & $\mathbf{x}$ & $\mathbf{x}$ & $\mathbf{x}$ \\
\hline 48 & 47 & 46 & 45 & 44 & 43 & 42 & 41 & 31 & 32 & 33 & 34 & 35 & 36 & 37 & 38 \\
\hline & & & 85 & 84) & (83) & (82) & (81) & (71) & (72) & 73 & (74 & $(75)$ & & & \\
\hline
\end{tabular}

Figure 2: Registration of the dental status.

Legend: X- missing tooth; $\mathrm{H}$ - healthy/intact tooth; $\uparrow$ - tooth in prefunctional eruptive phase.

According to the value of PLI $=0,54$, it concerns a patient with very good personal oral hygiene. There are no signs of clinical manifestation of gingival inflammation, no pathological alteration of the color or consistency of gingival tissue, no edema, no locations of bleeding, none anamnestic data of pain symptoms. The clinical situation of gingival health is ascertained by the gingival index equal to zero, GI=0. We have recorded normal depth of gingival sulcus in the range between 0,5 and $3 \mathrm{~mm}$.

Parents accentuate on the fact that they are concentrating their efforts for ensuring adequate oral health cares for their child by regular performance of tooth brushing procedures twice per day, morning and evening before going to bed. The toothpastes applied are fluoride containing, with precise dosage of fluorides according to the age of the child. The usage of "pea size" amount of fluoride tooth paste containing 500ppm F, as a form of exogenous fluoride prophylaxis, provides optimal prophylactic effect for hard teeth structures and anti-plaque accumulation effect for maintaining healthy gingival tissues, in condition of no risk of fluorosis.

On Figure 3 we illustrate the interrelations between the oral health status of children suffering from common health disorders and various environmental factors.

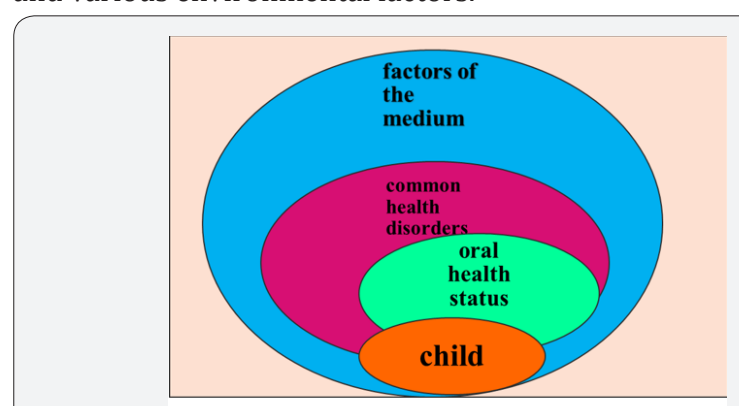

Figure 3: Correlation between oral health status and common health disorders.

\section{Discussion}

The absence of carious lesions in the child participating in that case report can be explained by the strict control exercised by parents regarding the specifics of the dietary regime. The limited consumption of sugar-containing foods and drinks only once per day during the main meal, and not immediately before going to bed, ensures stability of the $\mathrm{pH}$ level in saliva. The considerably decreased frequency of disaccharides' intake correlates to minimized episodes of $\mathrm{pH}$ value equal to 5,5 or lower, resulting in irreversible demineralization of hard teeth tissues [30]. Besides following precisely balanced principles of alimentary prophylaxis, parents of children with established diagnosis of autism must concentrate their efforts on supervision of the regularity and strictness of tooth brushing and additional oral hygiene measures appropriate for child's age [30]. The individual oral hygiene habits of the representative of that case report correspond to the significance of regular preventive measures combined with proper dietary habits [31].

Brodie et al. [32,33] devote their research on Valproic acid as an antiepileptic drug implemented for the purpose of proper control of various types of epilepsy. Eeg-Olofsson et al. [34] have not established any negative impact of valproic acid upon the periodontal apparatus of teeth in ten children with mixed and permanent dentition suffering from epilepsy. Irregular reciprocity has been ascertained between susceptibility of gingiva to valproic 
acid and patient's age. Ogunbodede et al. [35] established that $33.3 \%$ of patients taking only phenytoin are affected by pathological overgrowth of gingival tissue, progressing into gingival hyperplasia. The ratio of epileptic patients characterized with the state of gingival hyperplasia is elevated up to 83.3 $\%$, regarding these accepting combination of phenytoin with phenobarbitone. Based on profound investigations the scientific team proved that phenobarbitone has additive effect to phenytoin upon gingival enlargement. And in condition of monotherapy with phenobarbitone there is no clinical manifestation of gingival hyperplasia. The researchers Gurbuz and Tan have recorded the state of gingival hyperplasia in none of the investigated patients taking carbamazepine, in $16 \%$ of patients accepting phenobarbitone and in $42 \%$ of the participants into the study going through valproic acid-based therapy [24]. The active substances of valproic acid and carbamazepine exercise deteriorative influence upon neutrophils of patients resulting in disturbance of the frequency of the process of phagocytosis. The investigation reveals that in epileptic patients accepting combination of valproic acid and other antiepileptic drugs the buffer capacity of saliva is under critical levels, combined with considerable increase of the concentration of salivary protective enzyme of lysozyme [36]. The enhancement of the functionality of lysozyme as a fundamental ingredient of unstimulated saliva correlates to scientifically based evidence represented by Smith et al. [37] High levels of salivary lysozyme can be associated to lower rate of caries incidence in primary, mixed and permanent dentition of patients going through complex antiepileptic therapy. The caries-resistance of the child suffering from autism with accompanying condition of epileptic attacks, represented in our clinical case report, can be interpreted into the context of these studies' results.

Taking into consideration the fact that we cannot rely on full of value collaboration of children suffering from autism during dental procedures, there are fundamental rules to be strictly followed related to performance of efficient therapeutic cares [24] (Figure 4).

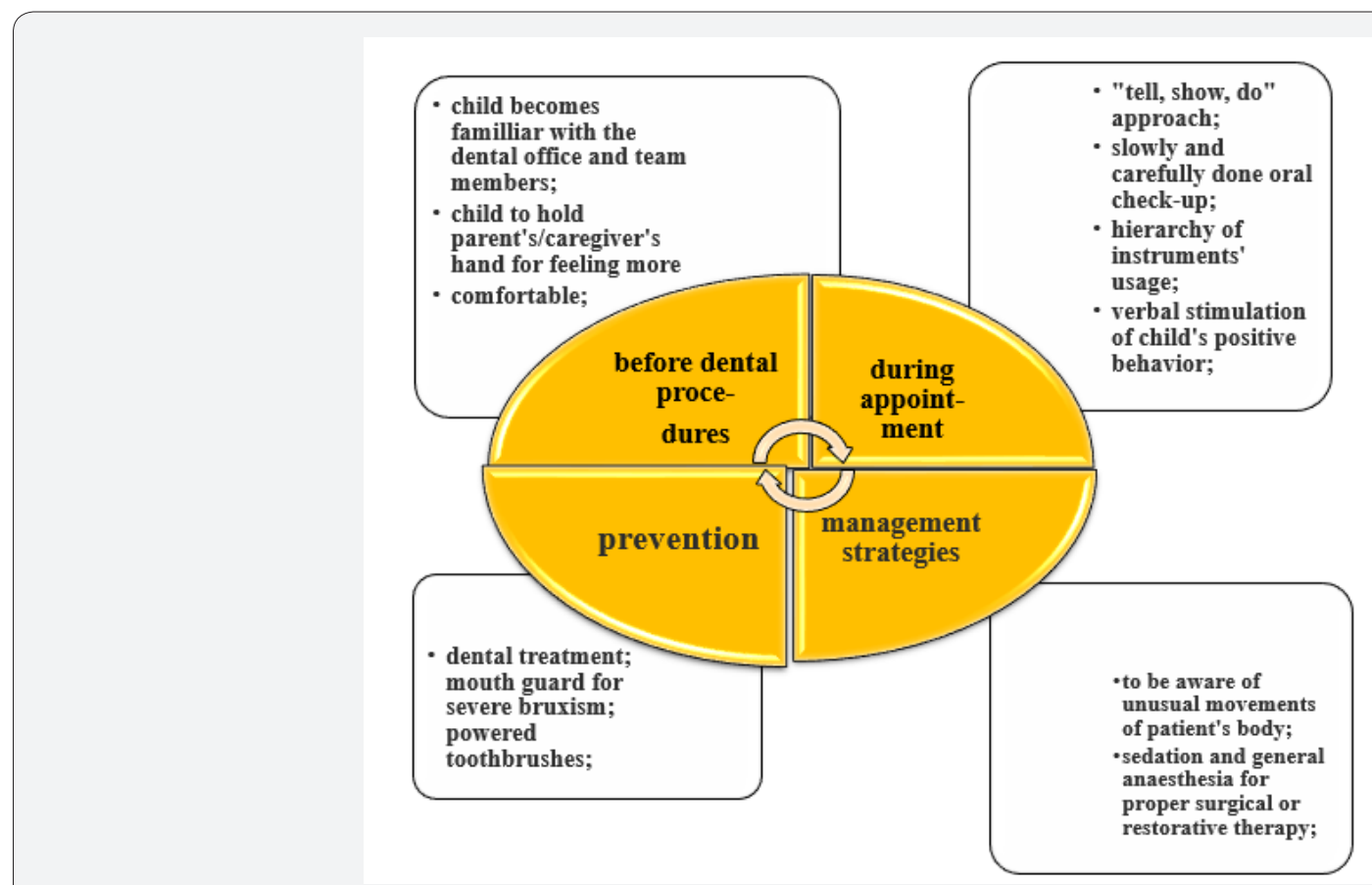

Figure 4: Therapeutic approaches and prophylaxis in children with autism.

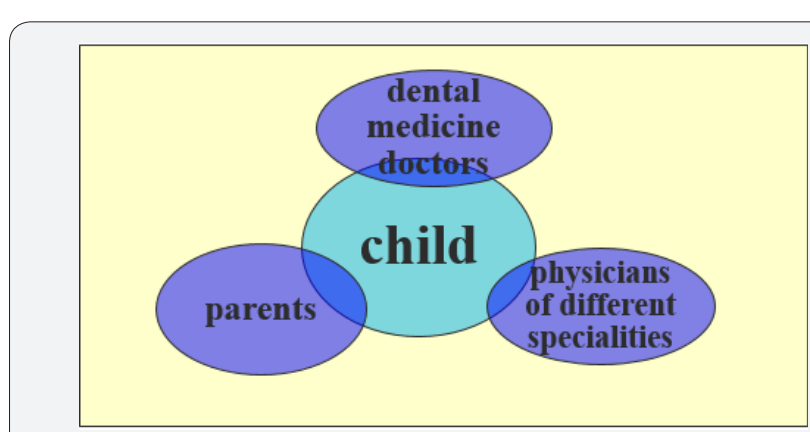

Figure 5: Collaboration between dental medicine doctors, physicians and parents.

\section{Conclusion}

In conclusion, on Figure 5 we accentuate on the fact that maintenance of proper common health status and oral health, respectively high quality of life, can be provided and ensured for children suffering from autistic spectrum disorder only when parents, dental medicine doctors and physicians of different professional scopes combine their efforts and collaborate with each other.

\section{References}

1. Kalyoncu IÖ, Tanboga I (2017) Oral Health Status of Children with Autistic Spectrum Disorder Compared with Non-authentic Peers. Iran J Public Health 46(11): 1591-1593. 


\section{Advances in Dentistry \& Oral Health}

2. Friedlander AH, Yagiela JA, Paterno VI, Mahler ME (2006) The neuropathology, medical management and dental implications of autism. J Am Dent Assoc 137(11): 1517-1527.

3. Loo CY, Graham RM, Hughes CV (2008) The caries experience and behavior of dental patients with autism spectrum disorder. J Am Dent Assoc 139(11): 1518-1524.

4. Xue Ming, Brimacombe M, Chaaban J, Zimmerman Bier B, Wagner GC (2008) Autism Spectrum Disorders: Concurrent Clinical Disorders. J Child Neurol 23(1): 6-13.

5. Sarnat H, Samuel E, Ashkenazi Alfasi N, Peretz B (2016) Oral health characteristics of pre-school children with autistic syndrome disorder. J Clin Pediatr Dent 40(1): 21-25.

6. Klein U, Nowak AJ (1998) Autistic disorder: a review for the paediatric dentist. Pediatr Dent 20(5): 312-317.

7. Cornacchio AL, Burneo JG, Aragon CE (2011) The Effects of Antiepileptic Drugs on Oral Health. J Can Dent Assoc 77: 140.

8. Aragon CE, Burneo JG (2007) Understanding the patient with epilepsy and seizures in the dental practice. J Can Dent Assoc 73(1): 71-76.

9. Miller CS, Damm DD (1992) Incidence of verapamil-induced gingival hyperplasia in a dental population. J Periodontol 63(5): 453-456.

10. Klar LA (1973) Gingival hyperplasia during dilantin-therapy; a survey of 312 patients. J Public Health Dent 33(3): 180-185.

11. Seymour RA, Smith DG, Turnbull DN (1985) The effects of phenytoin and sodium valproate on the periodontal health of adult epileptic patients. J Clin Periodontol 12(6): 413-419.

12. Delasnerie-Lauprêtre N, Turpin JC (1991) Evaluation of the prevalence of side effects of phenobarbital in patients in the Champagne-Ardenne region. Pathol Biol (Paris) 39(8): 780-784.

13. Thomason JM, Seymour RA, Rawlins MD (1992) Incidence and severity of phenytoin-induced gingival overgrowth in epileptic patients in general medical practice. Community Dent Oral Epidemiol 20(5): 288291.

14. Dahllöf G, Preber H, Eliasson S, Rydén H, Karsten J, et al. (1993) Periodontal condition of epileptic adults treated long-term with phenytoin or carbamazepine. Epilepsia 34(5): 960-964.

15. Perlík F, Kolínová M, Zvárová J, Patzelová V (1995) Phenytoin as a risk factor in gingival hyperplasia. Ther Drug Monit 17(5): 445-448.

16. Galas Zgorzalewicz B, Borysewicz Lewicka M, Zgorzalewicz M, Borowicz-Andrzejewska E (1996) The effect of chronic carbamazepine, valproic acid and phenytoin medication on the periodontal condition of epileptic children and adolescents. Funct Neurol 11(4): 187-193.

17. Ball DE, McLaughlin WS, Seymour RA, Kamali F (1996) Plasma and saliva concentrations of phenytoin and 5-(4-hydroxyphenyl)-5phenylhydantoin in relation to the incidence and severity of phenytoininduced gingival overgrowth in epileptic patients. J Periodontol 67(5): 597-602.

18. Sasaki T, Maita E (1998) Increased bFGF level in the serum of patients with phenytoin-induced gingival overgrowth. J Clin Periodontol 25(1): 42-47.

19. Trevisol-Bittencourt PC, da Silva VR, Molinari MA, Troiano AR (1999) Phenytoin as the first option in female epileptic patients? Arq Neuropsiquiatr 57(3B): 784-786.
20. Brunet L, Miranda J, Roset P, Berini L, Farré M, et al. (2001) Prevalence and risk of gingival enlargement in patients treated with anticonvulsant drugs. Eur J Clin Invest 1(9): 781-788.

21. Prasad VN, Chawla HS, Goyal A, Gauba K, Singhi P (2002) Incidence of phenytoin induced gingival overgrowth in epileptic children: a six month evaluation. J Indian Soc Pedod Prev Dent 20(2): 73-80.

22. Tan H, Gürbüz T, Dağsuyu IM (2004) Gingival enlargement in children treated with antiepileptics. J Child Neurol 19(12): 958-963.

23. Prasad VN, Chawla HS, Goyal A, Gauba K, Singhi P (2004) Folic acid and phenytoin induced gingival overgrowth-is there a preventive effect. J Indian Soc Pedod Prev Dent 22(2): 82-91.

24. Gurbuz T, Tan H (2010) Oral health status in epileptic children. Pediatr Int 52(2): 279-283.

25. Kamali F, Ball DE, McLaughlin WS, Seymour RA (1999) Phenytoin metabolism to 5-(4-hydroxyphenyl)-5-phenylhydantoin (HPPH) in man, cat and rat in vitro and in vivo, and susceptibility to phenytoininduced gingival overgrowth. J Periodontal Res 34(3): 145-153.

26. Dahllöf G, Axiö E, Modéer T (1991) Regression of phenytoin-induced gingival overgrowth after withdrawal of medication. Swed Dent J 15(3): 139-143.

27. Loe H (1967) The Gingival Index, the Plaque Index and the Retention Index Systems. J Periodontol 38(6): 610-616.

28. Listgarten MA (1980) Periodontal probing: what does it mean? J Clin Periodontol 7(3): 165-176

29. Angelopoulos AP, Goaz PW (1972) Incidence of diphenylhydantoin gingival hyperplasia. Oral Surg Oral Med Oral Pathol 34(6): 898-906.

30. Lowe O, Lindemann R (1985) Assessment of the autistic patient's dental needs and ability to undergo dental examination. ASDC J Dent Child 52(1): 29-35.

31. Morgan S, Taylor E (2007) Antipsychotic drugs in children with autism BMJ 334(7603): 1069-1070.

32. Joshi NH, Deshpande AN, Deshpande NC, Rathore AS (2017) Comparative evaluation of oral hygiene status and gingival enlargement among epileptic and healthy children as related to various antiepileptic drugs. J Indian Soc Periodontol 21(2): 125-129.

33. Brodie MJ, Dichter MA (1996) Antiepileptic drugs. N Engl J Med 334(3): 168-175.

34. Eeg-Olofsson O, Lundström A, Hamp SE (1983) Oral state of children with epilepsy on treatment with sodium valproate. Scand J Dent Res 91(3): 219-223.

35. Ogunbodede EO, Adamolekun B, Akintomide AO (1998) Oral health and dental treatment need in Nigerian patients with epilepsy. Epilepsia 39(6): 590-594

36. Caldiroli E, Marino F, Cosentino M, De Ponti F, Fietta AM, et al. (1998) Peripheral benzodiazepine receptor expression on leukocytes and neutrophil function during anticonvulsant monotherapy. Pharmacology 57(4): 215-221.

37. Smith QT, Hamilton MJ (1981) Salivary composition, phenytoin ingestion and gingival overgrowth. J Periodontol 52(11): 673-679. 


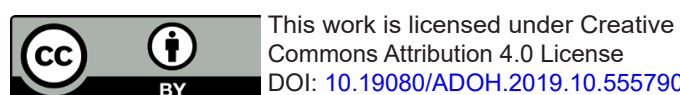

\section{Your next submission with Juniper Publishers} will reach you the below assets

- Quality Editorial service

- Swift Peer Review

- Reprints availability

- E-prints Service

- Manuscript Podcast for convenient understanding

- Global attainment for your research

- Manuscript accessibility in different formats ( Pdf, E-pub, Full Text, Audio)

- Unceasing customer service

Track the below URL for one-step submission https://juniperpublishers.com/online-submission.php 